Volume 15

Issue 3 Mass Atrocity and Collective Healing

Article 10

$12-21-2021$

\title{
Legacies of Slavery and their Enduring Harms
}

Scherto R. Gill

GHFP Research Institute/University of Wales Trinity St. David

Follow this and additional works at: https://digitalcommons.usf.edu/gsp

\section{Recommended Citation}

Gill, Scherto R. (2021) "Legacies of Slavery and their Enduring Harms," Genocide Studies and Prevention: An International Journal: Vol. 15: Iss. 3: 66-82.

DOI:

https://doi.org/10.5038/1911-9933.15.3.1833

Available at: https://digitalcommons.usf.edu/gsp/vol15/iss3/10

This Articles is brought to you for free and open access by the Open Access Journals at Digital Commons @ University of South Florida. It has been accepted for inclusion in Genocide Studies and Prevention: An International Journal by an authorized editor of Digital Commons @ University of South Florida. For more information, please contact digitalcommons@usf.edu. 


\title{
Legacies of Slavery and their Enduring Harms
}

\author{
Scherto R. Gill \\ Global Humanity For Peace Institute \\ University of Wales Trinity Saint David \\ Guerrand-Hermès Foundation for Peace
}

Human suffering anywhere, concerns men and women everywhere. ${ }^{1}$

\section{Introduction}

On March 25, 2020, in his message for the International Day of Remembrance of the Victims of Slavery and the Transatlantic Slave Trade, the UN Secretary General António Guterres highlighted that for humanity to move forward towards a flourishing future, it requires us to collectively confront slavery's racist legacy. The changing contexts and evolving symptoms of relevant historical, transgenerational, and cultural traumas and connected wounds have meant that our approaches to addressing the legacies of slavery must equally become wide-ranging. Some shifts in communities' responses have already been observed, from civil rights movements, to civil disobedience and resistances; from challenging the ideological reproduction of social relations, to conceptualizing the interconnection between subjectivity, desire, and power; from wrestling with the specificities of race, culture, and nationhood, to proposing ways to move beyond race and embrace hybridity and cosmopolitan humanism. ${ }^{2}$ For instance, UNESCO's teaching, General History of Africa and calling for global Africa can be regarded as such an innovative step towards its intention to free the African continent and its peoples from racial prejudices resulting from the transatlantic trade of enslaved Africans and colonization. Similarly, the most recent Brazilian Aquilombamento in politics is such an attempt to expand the anti-racist response from defending the rights of Black people, to defending all those who are made socially vulnerable, including the poor, the LGBTQ community, and others. However, despite these shifting responses, the legacies of slavery and the enduring harms have yet to be fully understood and confronted.

As demanded by the most recent Black Lives Matter, and other similar movements, such an understanding will enable relevant historical and contemporary actors to fully recognize their respective parts in these legacies and their continued harrowing effects on peoples, communities, and societies. More importantly, a deeper understanding of the legacies of transatlantic slavery and their harmful effects will encourage responsibilities from leaders of those countries whose prosperities have been built upon layers of historical damage done to the enslaved and their descendants. These national governments must properly accept their responsibilities for the historical acts of inhumanity and for addressing the unrelenting economic, political, psychosocial, and spiritual consequences. Indeed, to acknowledge this history, and its multifarious living legacy would mean to admit that acts of dehumanization and instrumentalization had been carried out at unprecedented magnitude, including genocide, forced displacement, incarceration, enslavement, murder, and more. Such reckoning can invite deep reflection on systemic change from the relevant governments, corporations, institutions, and communities that have continuously profited from this history and its legacies. It also enables global leaders to explore the potential for collective healing that such reckoning and subsequent acts of reparation and commitment to address racial injustice can inspire.

\footnotetext{
${ }^{1}$ Elie Wiesel, Night (New York: Bantam Books, 1960).

2 Paul Gilroy, The Black Atlantic: Modernity and Double Consciousness (London: Verso, 1993); Gayatri Spivak, "Can the Subaltern Speak?," in Marxism and the Interpretation of Culture, ed. Cary Nelson and Lawrence Grossberg (London: Macmillan, 1988); Cornel West, Race Matters (Boston: Beacon Press, 1993).
} 
This article provides a much-needed inquiry into legacies of slavery from an interdisciplinary perspective, including the historical, socioeconomic, political, and the epistemic. It makes an important distinction between legacies of slavery and their persisting damages. By investigating these legacies' effects on peoples, communities, and societies, it highlights the imperative of situating the pains and sufferings of historical traumas within contemporary structural oppression and institutional discrimination that have perpetuated these harms. The article consists of four sections: first, it outlines the legacies of slavery, comprised in instrumentalizing black bodies for economic gains, employing political aggression to colonize both lands and minds, applying racialized discourse to demean and dehumanize, and oppressing people of African descent, or Afrodescendants, through structural violence. It then discusses these injuries as transgenerational and cultural traumas, and how these wounds are experienced by the relevant communities. The third section focuses on racism as a significant harm, analyzing different forms of racism (internalized, interpersonal, and institutional) as interconnected and mutually reinforcing. To conclude, this article considers challenges in addressing legacies of slavery and puts forward tentative ideas for collective healing.

\section{Legacies of Slave Trade and Slavery}

Transatlantic slave trade took place during 16th and the end of 19th century, involving forcing tens of millions of Africans into enslavement who were shipped to Europe and North America. ${ }^{3}$ Countries such as Portugal, Britain, France, Spain, the Netherlands, Sweden, and the USA were amongst the traders enslaved Africans and beneficiaries of mass enslavement of Africans and indigenous people. Although there have been varying forms of slave trade and slavery throughout human history, the transatlantic slave trade and slavery, in the scale, the transgenerational nature, the use of violent incarceration, and the commodification of human beings, was an unprecedented form of brutality. ${ }^{4}$ The appalling inhumanity illustrated that enslaved Africans were treated as commodities and black bodies were subjugated to unimaginably cruel conditions of labor and life. ${ }^{5}$ The underlying purpose of enslavement was economic gain, e.g., wealth generation and accumulation. ${ }^{6}$ Violence was a major instrument of control, which served a function of colonization (body, mind, spirit, culture) through a climate of ever-lasting fear to coerce the submission of the enslaved. ${ }^{7}$

A typical assumption is that transatlantic slave trade and slavery took place centuries ago, and we should let bygones be bygones. However, as analyzed here, this history is alive today, manifested in psychological slavery rooted in structural dehumanization. This unhealed trauma has now been ingrained in our contemporary societies, permeating many aspects of our personal and communal lives, and affecting not only the black, the indigenous, and other nonEuropean communities, but also the communities of European descent. The legacies have continued to wreak havoc on our global economic and political systems, structural features, and institutional practices within which the lived realities of all peoples and communities unfold along the color line. ${ }^{8}$

Dehumanizing is a word that has been frequently used to characterize the nature enslavement, white supremist ideology, and other violent practices towards people of African

\footnotetext{
3 Ira Berlin, Generations of Captivity: A History of African-American Slaves (Cambridge: Harvard University Press, 2003); Eric Williams, Capitalism and Slavery (London: University of North Carolina Press, 1994).

4 Paul E. Lovejoy, Transformations in Slavery: A History of Slavery in Africa (Cambridge: Cambridge University Press, 2012).

${ }_{5}$ Philip Atiba Goff et al., "Not Yet Human: Implicit Knowledge, Historical Dehumanization, and Contemporary Consequences," Journal of Personality and Social Psychology 94, no. 2 (March 2008).

${ }^{6}$ William E. B. Du Bois, The W.E.B. Du Bois Collection (New York: Blackmore Dennett, 1999).

7 Joy DeGruy Leary, Post Traumatic Slave Syndrome: America's Legacy of Enduring Injury and Healing (Milwaukie: Uptone Press, 2005)

${ }^{8}$ Michael T. Martin and Marilyn Yaquinto, “Reparations for 'America's Holocaust:' Activism for Global Justice," Race and Class 45, no. 4 (April 2004).
} 
descent. However, this article has avoided describing these peoples and their communities as being dehumanized. ${ }^{9}$ The very idea that enslavement can dehumanize the enslaved is misleading if not harmful as it implies that "their humanity needs to be proven again and again." 10 This is an important distinction for any discussion about legacies of slavery: the enslaved/oppressed are already human beings, and as human beings, their humanity cannot be taken away, despite being subject to brutality. A person's humanity is always present in their thought, work, language, songs, being and acting, regardless the conditions under which their lives are lived.

By contrast, an act can be dehumanizing. ${ }^{11}$ What makes an act dehumanizing is that it intends to treat persons inhumanly, deprive them from living fully as human beings, and alienate them from human dignity. ${ }^{12}$ In this understanding, an act can be dehumanizing for both the actor and those being acted upon. ${ }^{13}$ As such, the actor who imposed acts of violence upon the enslaved, and the enslaved who were at the receiving ends of such violent acts, were entangled in the same self-alienation, e.g., being estranged from human dignity. ${ }^{14}$ There is, however, a fundamental difference in their experience of self-alienation: the former might feel this alienation a sign of power as it appears to affirm their humane existence, and the latter demeaned by this alienation as it seems to confirm their inhumane existence. Therefore, rather than being mutually dehumanized, acts of enslavement and brutality estranged both the enslaver and the enslaved from living out their human dignity.

To understand the impacts of slavery's legacies, we investigate three historically significant processes that paved the "economic," "political," and "ideological" ground for enabling the transatlantic slave trade and slavery. Seldom examined together, in this article, we argue that these processes were operated systematically in mutually reinforcing ways in order to make mass enslavement possible. Firstly, economic theories were applied to prioritize wealth accumulation over the intrinsic worthwhileness of human beings. Thus, atrocity against enslaved Africans was normalized, in the name of economic growth for the benefit of material well-being, by slave owners, plantation owners, other citizens or consumers, and public institutions, such as churches, and governments. ${ }^{15}$ Secondly, rationalized political exclusion was introduced to support the normalcy of brutality against black bodies. Thirdly, the economic and political agenda was further strengthened by Europeans fabricating and instituting a racialized discourse to enable the full exploitation of African and indigenous people. ${ }^{16}$ Together, these economic, political, and ideological processes instilled a binary of white superiority and black inferiority, fueling the colonization and oppression of peoples of African and indigenous descent. ${ }^{17}$ Although our discussion visits each of these processes separately below, the purpose is to develop an understanding of how they functioned interdependently.

\footnotetext{
9 Walter Johnson, “To Remake the World: Slavery, Racial Capitalism, and Justice," Boston Review, February 20, 2018, accessed April 20, 2021, http:/ / bostonreview.net/ forum/walter-johnson-to-remake-the-world.

11 Nick Haslam, "Dehumanization: An Integrative Review," Personality and Social Psychology Review 10, no. 3 (August 2006).

12 Human dignity is a notion rooted in the Kantian concept of "Categorical Imperative," maintaining that persons cannot be treated as a mere means, a fundamental moral principle affirming human's intrinsic worthwhileness which constitutes our dignity. This argument has been supported by philosophers and theologians across cultures.

${ }^{13}$ Here we stress the dehumanizing effect of an act rather than discussing whether a person remains human when they are treated inhumanely or whether a person remains human when they treat others inhumanely. When an act is dehumanizing, it exhibits the actor's failure to recognize other persons' dignity as human beings, and it equally demonstrates the actor's failure to recognize and act upon their own dignity as a human being.

${ }^{14}$ Karl Marx, "Economic and Philosophical Manuscripts of 1844," in Early Writings, trans. Rodney Livingstone and Gregor Benton (London: Penguin, 1992).

${ }^{15}$ Ibid.

${ }^{16}$ Franz Fanon, Black Skin, White Masks, trans. Charles Lam Markmann (London: Pluto Press, 1986).

${ }_{17}$ Sirpa Salenius, "Troubling the White Supremacy-Black Inferiority Paradigm: Frederick Douglass and William Wells Brown in Europe," Journal of Transatlantic Studies 14, no. 2 (2016).
} 
The economic factor was influential in enabling acts of inhumanity. ${ }^{18}$ Capitalist economy has since been identified as "racial capitalism," 19 owing to the historic interconnections between transatlantic slave trade and slavery, and capitalism. ${ }^{20}$ It was the raison d'être of capitalist economy, i.e. the ceaseless acquisition of profit and accumulation of wealth, that had made systematically subjugating human beings to violent exploitation and enslavement desirable. ${ }^{21}$ In this way, slavery and capitalism were interconnected "due to the expression of power, greed, and self-interest in both and the wide range of potential outcomes in a capitalistic society." 22 Hence the conclusion that "the history of capitalism makes no sense separate from the history of the slave trade and its aftermath. There was no such thing as capitalism without slavery." 23 Without an awareness of slavery's historical role in capitalist expansion, and the interconnection between slavery and capitalism, societies can be blinded to the continued violence and colonization until now. ${ }^{24}$ By connecting race and capitalism, or calling it racial capitalism, we highlight the pernicious nature of capitalist economy that relies on the production, and reproduction, and instrumentalization of human differences.

Historically, race, through its emphasis on visible physical differences between groups in terms of the color of skin, texture of hair, and other physical features, has been used as an excuse for capitalist exploitation. Forcefully enslaving and trading Africans, displacing native people, conquering their lands, robbing them of natural resources, and applying unjust market methods to exclude the colonized are illustrative of racist capitalism..$^{25}$ Since transatlantic brutality, capitalism has further permitted contemporary abuse of human differences to go beyond race, including gender, ethnicity, class, ability, age, sexuality, and so forth. ${ }^{26}$ Thus legacies of slavery become living legacies.

Many political institutions have contributed to wealth pursuit and capitalist expansion, ${ }^{27}$ and in our case, at the expense of non-European other. Structurally, European political power had helped determine the direction and processes of economic growth, e.g., through laws, and played a significant part in the development of economic institutions, and in supporting trades and industrial productions, such as cotton. Seeing it from this joint perspective, slavery was both an economic and political need, and violent racist capitalism and elite control of political processes were compatible. ${ }^{28}$ Following the abolition of slavery on both sides of the Atlantic, structural dehumanization has

18 See for e.g., Mark Stelzner, “Slavery and Capitalism,” Labor History 61, no. 3-4 (April 2020); Sven Beckert and Seth Rockman, eds. Slavery's Capitalism: A New History of American Economic Development (Philadelphia: University of Pennsylvania Press, 2016); Joseph E. Stiglitz, The Price of Inequality: How Today's Divided Society Endangers Our Future (New York: W. W. Norton \& Company, 2012).

${ }^{19}$ See for e.g., Cedric J. Robinson, Black Marxism: The Making of the Black Radical Tradition (Chapel Hill: University of North Carolina Press, 1983); Andrew J. Douglas, “W. E. B. Du Bois and the Critique of the Competitive Society," Du Bois Review: Social Science Research on Race 12, no. 1 (January 2015), accessed April 21, 2021, https://doi.org/ 10.1017/S1742058X14000344; Robin D. G. Kelley, “What did Cedric Robinson Mean by Racial Capitalism?” Boston Review, January 12, 2017, accessed April 20, 2021, http:/ / bostonreview.net/race/robin-d-g-kelley-what-did-cedricrobinson-mean-racial-capitalism.

${ }^{20}$ Edward Baptist, The Half Has Never Been Told: Slavery and the Making of American Capitalism (New York: Basic Books, 2016); Sven Beckert, Empire of Cotton: A Global History (London: Vintage, 2015).

${ }^{21}$ Beckert, Empire of Cotton; Deivison M. Faustino, "The Wretched of COVID-19 in Brazil: Colonial Spectres of an Announced Crisis." Agrarian South: Journal of Political Economy 10, no. 1 (April 2021), 173-183.

22 Stelzner, Slavery and Capitalism, 335.

${ }^{23}$ Johnson, To Remake the World.

24 Ibid.

25 Stelzner, Slavery and Capitalism.

${ }^{26}$ Michael Ralph and Maya Singhal, “Racial Capitalism," Theory and Society 48 (December 2019), accessed April 21, 2021, https:// doi.org/10.1007/s11186-019-09367-z.

27 Daron Acemoglu et al., "Institutions as a Fundamental Cause of Long-Run Growth," in Handbook of Economic Growth, Volume 1A, ed. Philippe Aghion and Steven N. Durlauf (Amsterdam: Elsevier, 2005).

28 Ibid. 
sustained legacies of slavery through political mechanisms, e.g., colonialism and imperialism, that contrive to serve wealth-oriented economic aims.

Throughout histories of Europe and Americas until now, constitutions (e.g., counting a black person as three-fifths of a person to enhance the voting power of white males in the US southern states), national laws (e.g., Slave Compensation Act 1837 in the UK), militarization of police, exclusive educational investment, and uneven finance policies across the Atlantic, and so forth, are illustrations of structural violence. Take the police brutality against black and indigenous people as an example. In the US, the police forces and agencies' deep-seated racialized practices and racial discrimination, and African Americans' increased involvement in criminal activities are mutually reinforcing phenomena owing to the living legacies of slavery. ${ }^{29}$ Similarly, in Latin America, race regulation customary laws have tended to naturalize a racial hierarchy, establishing white supremacy in European settler colonies as well as in contemporary postcolonial societies..$^{30}$ Likewise, amongst African communities, both in the diasporas and across the Africa continent itself, the widespread experiences of economic underdevelopment, social deprivation, and political turmoil can be linked to global structural dehumanization that informs national and international policies and how they are enacted by governments and institutions. ${ }^{31}$

To legitimize the trade of enslaved African peoples, and to prepare an ideology to underpin economic exploitation and political oppression, from the start, a racist discourse was fabricated by European scholars and researchers, depicting blacks as brutish, animalistic, aggressive, violent, and dangerous. ${ }^{32}$ Racial discrimination was also visible in European Enlightenment thought whereby blacks were depicted as primitives (e.g., with primitive minds), in contrast with whites who were regarded as civilized, and intellectually superior. ${ }^{33}$ Racist European epistemological paradigm was imposed to formulate "truth," "knowledge," and "reality" of Africans. ${ }^{34}$ It served to enable first the mass enslavement, then colonization, and now systematic oppression of Africans. This historically contingent relationship between slavery and blackness has thus prevailed.

The deployment of racist discourse and epistemology hence inculcated a racist ideology. Physiological differences were translated into binary distinctions between human "races," and race, thereby became a classifying category for exclusion, inequality, and injustice. ${ }^{35}$ Skin color, hair, ethnicity, belief, cultural practice, and other physical distinctions were part of the anthropological and historical knowledge used to define the inferiority of the black other. Once established, this racist ideology, although introduced and developed to justify the enslavement of Africans, has perpetuated a hierarchy of human beings. Racist ideology then evolved into white supremacist ideology. ${ }^{36}$ It was precisely this focus on "race," and the evolving white supremacist mentality

${ }^{29}$ Akwasi Owusu-Bempah, "Race and Policing in Historical Context: Dehumanization and the Policing of Black People in the 21st Century," Theoretical Criminology 21, no. 1 (February 2017); Nicole Gonzalez Van Cleve and Lauren Mayes, "Criminal Justice Through 'Colorblind' Lenses: A Call to Examine the Mutual Constitution of Race and Criminal Justice," Law \& Social Inquiry 40, no. 2 (February 2015), accessed April 21, 2021, https://doi.org/10.1111/ $\underline{\text { lsi.12113. }}$.

30 Jean Muteba Rahier, "Evaluating the Usefulness of Contemporary Ethnoracial Law for Afrodescendants in Latin America through the Examination of Court Cases and the Appreciation of the State's Processual Nature," Latin American and Caribbean Ethnic Studies 14, No. 3 (2019), 215-233.

31 Owusu-Bempah, Race and Policing; Van Cleve and Mayes, Criminal Justice.

32 Laura T. Fishman, "The Black Bogeyman and White Self-Righteousness," in Images of Color, Images of Crime, ed. Coramae Richey Mann et al. (New York: Oxford University Press, 2006).

33 See analysis of Locke, Hume, Kant and Voltaire's claims in Charles W. Mills, The Racial Contract (Ithaca: Cornell University Press, 1997).

34 See for e.g., Mogobe B. Ramose, African Philosophy Through Ubuntu (Harare: Mond Books, 1999).

35 W. E. B. Du Bois, The Souls of Black Folk (Boston: Bedford Books, 1903); Carter G. Woodson, The Mis-Education of the Negro (San Diego: Book Tree, 1933).

36 Coretta Phillips and Benjamin Bowling, "Racism, Ethnicity and Criminology: Developing Minority Perspectives," British Journal of Criminology 43, no. 2 (March 2003); Annette Gordon-Reed, "America's Original Sin: Slavery and the Legacy of White Supremacy," Foreign Affairs 97, no. 1 (January/February 2018). 
and practices that distinguish transatlantic slavery from other forms of slavery in human history. Thus slavery "created a defined, recognizable group of people and placed them outside society... slavery was an inherited condition." 37

Also established were the assumptions of Eurocentrism or European singularity, resulting in a discriminatory global system of injustice. ${ }^{38}$ The Eurocentric approach normalized the lens through which to examine, analyze, dissect, and ultimately instrumentalize and oppress non-European other. It also subjected non-Europeans to Eurocentric standards, demands, and requirements. ${ }^{39}$ Edward Said's orientalism is the recognition that our world is separated into "two unequal halves," 40 the West or European, and the Orient, or the nonEuropean, which "has helped to define Europe (or the West) as its contrasting image, idea, personality, experience." 41

This active othering of peoples of African, indigenous, and other non-European descent has become a key component of the continued legacies of slavery. In particular, a Eurocentric epistemic basis has allowed non-European Other to be degraded, controlled, and brutalized. Such an epistemic framework served as a rationalized moral ground for European colonization, domination and exploitation of Africa, Latin America, Asia, and other parts of the world. These legacies are now manifested in, for example, "global economic disparities," especially in the phenomena of Africans leaving the continent and becoming vulnerable in Europe and North America, and the mistreatment of illegal African migrants across the globe, such as their being subjugated to police brutality, in "a racialized carceral system." 42 In Brazil, a myth of multiracial and multicultural society masks racial whitening, a subtle mechanism of racial exclusion, whereby the dominant elites prevent peoples of non-white communities from becoming aware of their being victimized in society. 43

Through legacies of transatlantic slavery, perpetuated by structural violence and systemic injustice prevailing in Europe, the Americas, and formerly European colonized regions, including Africa and Asia, race becomes so deeply entangled in Western historical, economic, political, ideological, and epistemological processes that any attempts to redefine it will necessarily create conflicts and tensions. ${ }^{44}$ The effort to undo racialized injustice as a way to address the legacy of slavery will only be "a long, protracted struggle, carried out over generations." 45

\section{Transgenerational and Cultural Traumas as Enduring Harms of Slavery's Legacies}

Today, the socio-economic and political institutions that once enabled slavery remain in place and exert significant impact on people's experiences of human dignity and well-being in the contemporary world. ${ }^{46}$ Despite the abolition of slavery in Europe and the Americas at the end of the 19th century, the regime of terror has continued to inflict harrowing stress on many generations of people of African and indigenous descent. ${ }^{47}$ To most people, this would be

\footnotetext{
37 Ibid.

38 Ibrahima Thiaw and Deborah L. Mack, "Atlantic Slavery and the Making of the Modern World: Experiences, Representations, and Legacies," Current Anthropology 61, no. S22 (October 2020).

39 Andrew S. Curran, The Anatomy of Blackness: Science and Slavery in an Age of Enlightenment (Baltimore: Johns Hopkins University Press, 2011).

40 Edward W. Said, Orientalism (New York: Vintage, 1979), 5.

41 Ibid., 2.

42 Thiaw and Mack, Atlantic Slavery, S148.

43 Diego dos Santos Reis, "Crossroads Knowledge: (De)Coloniality, Epistemic Racism and Philosophy Teaching," Education, Democracy and Difference 36, no. e75102, (2020).

44 Thiaw and Mack, Atlantic Slavery, S148.

45 James B. McKee, “Race: Changing Context, Changing Perspective," Michigan Sociological Review 11 (Fall 1997$), 1$.

46 Graziella Bertocchi, "The Legacies of Slavery In and Out of Africa," IZA Journal of Migration 5 (August 2016), accessed April 21, 2021, https:/ /izajodm.springeropen.com/articles/10.1186/s40176-016-0072-0.

47 Goff et al., Not Yet Human.
} 
surprising; however, today, more than four hundred years after the first enslaved Africans were brutally and violently brought to the Atlantic shores, the catastrophic wounds of slavery and their harmful effects remain far-reaching. The suffering is not limited to the physical, psychological, and spiritual harms endured by the descendants of the formerly enslaved, these harms are also experienced as collective trauma within an overall culture of institutionalized oppression, the toxin of which has contaminated global societies.

The harms of slavery's legacies are manifold, from the massive and tragic loss of human lives, to the irreversible materialistic loss for Africa and for the world; from the deprivation of human dignity, to the damage to our personal and collective psyche that has internalized the effects of the harm; from self-alienation, to dehumanizing interpersonal and intergroup, and intercommunal relationships. Without recognition, acknowledgement nor healing of the historic trauma and legacies, harms have been passed on, continuing to fester in successive generations, and extending the wounds and hurts to generations yet to come. It is therefore critically important to examine how the traumatic effects of slavery's legacies are lived and transmitted by peoples and communities, and how they inflict wide-spread harms. Only with such an understanding can global societies and communities begin to address these legacies and heal their lingering wounds.

The legacy of slavery is first and foremost experienced as trans-generational trauma, commonly referred to as the transmission of specific painful and stressful elements of historical events within large groups of individuals from one generation to another. ${ }^{48}$ As a profound collective trauma, slavery had a tormenting impact on enslaved Africans physically, mentally, emotionally, spiritually, and relationally. ${ }^{49}$ Such unhealed trauma can be passed on through parenting processes and behavior patterns of communities and societies..$^{50}$ Equally, the wounds can be transmitted through the continued injuries from the economic-political systems, psycho-social processes, and institutional practices. ${ }^{51}$ It can further prevail across generations through epigenetic mechanism. ${ }^{52}$ Descendants from both sides of mass atrocity, including victims/survivors, perpetrators, and even bystanders, may share common responses to pain and stress, through, for instance, avoidance, numbness, denial, and silence, as ways to cope with the profound indescribable experiences. ${ }^{53}$ The trauma, although not directly undergone by the descendants of those traumatized, may have effects on the successive generations through inherited trauma reactivity being triggered in similar stressful situations.

Symptoms of transgenerational trauma commonly found in people of African descent tend to be both self- and other-directed. Low primary self-esteem, distorted self-concept, learned helplessness, hopelessness, depression, destructive and risk-taking behaviors, and self-violence are amongst self-directed trauma symptoms; ${ }^{54}$ whereas distrust, suspicion, anger, aggression, and antipathy and violence against others, including one's own family, friends, members of one's own and other communities are illustrative of other-directed symptoms. ${ }^{55}$ These behaviors and emotional states adopted by people of African descent in contemporary western societies are inherited from their enslaved ancestors, and triggered by systemic oppression and structural violence. In addition,

48 Vamik D. Volkan, Large-Group Psychology: Racism, Societal Divisions, Narcissistic Leaders and Who We Are Now (London: Phoenix, 2020).

49 DeGruy Leary, Post Traumatic Slave Syndrome.

50 Thomas Hübl and Julie Jordan Avritt, Healing Collective Trauma: A Process for Integrating Our Intergenerational and Cultural Wounds (Louisville: Sounds True, 2020).

51 Volkan, Large-Group Psychology; Rachel Yehuda and Linda M. Bierer, "The Relevance of Epigenetics to PTSD: Implications for the DSM-V," Journal of Traumatic Stress 22, no. 5 (October 2009), accessed April 21, 2021, https:// doi.org/10.1002/jts.20448.

52 Frances A. Champagne, "Epigenetic Legacy of Parental Experiences: Dynamic and Interactive Pathways to Inheritance," Development and Psychopathology 28, no. 4.2 (Sept 2016), 1219-1228, https://doi.org/10.1017/ $\underline{\mathrm{S} 0954579416000808}$

53 Dan Bar-On, The Indescribable and the Undiscussable: Reconstructing Human Discourse After Trauma (Budapest: Central European University Press, 1999).

54 DeGruy Leary, Post Traumatic Slave Syndrome.

55 Ibid. 
there are also indications that oppression has been internalized and accepted by the communities of African descent who may exhibit a lack in self agency, and a feeling of disempowerment. ${ }^{56}$ For instance, research has found that amongst peoples in the Caribbean, transgenerational trauma has sustained slavery, in the form of "mental slavery." 57

Furthermore, shared traumatic experiences can be embedded within a culture, thus becoming cultural trauma. Like transgenerational trauma, cultural trauma occurs when members of a large group had been subjugated to horrifying experiences that profoundly impacted upon group members shared consciousness, scarred their memories and shaped their present and future identity in irrevocable ways. ${ }^{58}$ Hostile encounters, such as enslavement, colonization and segregation, underlie the psychosocial ramifications of cultural pains, which are transmitted down the generations, affecting descendants of the enslaved collectively. 59

Symptoms of cultural trauma can involve both normalized practices and processes of identity-formation. In the case of normalized practices, it has been noted, for instance, that contemporary African American parents tend to apply strict disciplines on their children, including the use of beating, and they seldom praise their children, but denigrate them instead, especially in front of strangers..$^{60}$ The origin of such practices was chattel slavery whereby the enslaved must shield children from the masters' attention which might result in harsher punishment on the children, such as being removed from parents, sold, or killed. ${ }^{61}$ These protective measures applied by the enslaved were normalized within the African American community, passed on, and became a symptom of cultural trauma. In terms of identify-formation, cultural trauma can be experienced as a dramatic loss of self-identity, coherence, and meaningfulness. ${ }^{62}$ Often the formation of group identity requires the centrality of collective memory, interpretation and representation of the past in the process of developing self-concept, group bonding, and a sense of belonging. An example is the process whereby collective memory of enslavement, colonization, and displacement from lands has served to construct (and deconstruct) Afrodescendants' identity in Brazil, as in the discourse of "quilombo." Originally referring to a runaway slave community, quilombo now embodies myriad struggles Afrodescendants must confront. In this way, cultural trauma occurs and accrues, distorting and regenerating societal perceptions and resulting in misapprehensions and misperceptions of color, and race, and harmful stereotypes and beliefs. ${ }^{63}$ Unconscious codes, values, and language built into the society's memory and remembrance can become cultural norms, and further extend and prolong the historical trauma. ${ }^{64}$

The hurtful effects of both transgenerational and cultural trauma are not limited to the harms to the descendants of the enslaved people; they likewise have impact on the direct and indirect beneficiaries of the slave trade and slavery, and the contemporary groups who have continued to profit from the dehumanizing history. 65 Thus, legacies of slavery, manifested in colonization, structural violence, and institutional oppression, are trauma beyond individualistic experiences, felt as collective catharsis to channel aggression and antagonism to oneself, and to others. ${ }^{66}$ For people of African and indigenous descent, experiences of social deprivations, exclusions, political disempowerment, and economic injustice are part and parcel

\footnotetext{
56 Ibid.

57 Barbara Fletchman Smith, Mental Slavery: Psychoanalytic Studies of Caribbean People (London: Karnac Books, 2000).

58 Jeffery C. Alexander, et al. Cultural Trauma and Collective Identity (Berkeley: University of California Press, 2004).

59 The formation of black people's identity in the US is such an illustration. Ron Eyerman, Cultural Trauma: Slavery and the Formation of African American Identity (Cambridge: Cambridge University Press, 2001).

60 DeGruy Leary, Post Traumatic Slave Syndrome.

61 Ibid.

62 Eyerman, Cultural Trauma.

63 Hübl and Avritt, Healing Collective Trauma.

64 Ibid.

${ }^{65}$ Michael Banton, "Race as a Social Category," Race 8, no. 1 (July 1966).

66 Fanon, Black Skin.
} 
of systemic oppression. However, on a practical level, each of these harms can serve as a reminder of internalized social norms and self-identification to reinforce the idea that their black skin is the cause of their sufferings. In other words, when a lowest status is imposed on black people, it creates the Negro myth, a value system that judges people of African descent to be lacking in social and political worthwhileness. ${ }^{67}$ Collective memories and grievances of slavery and related atrocity have evidently led to hostile relationships between social groups and communities, feeding an antagonistic attitude of us-versus-them, perpetuating cycles of violence.

\section{Contemporary Racism as a Significant Harm of Slavery's Legacies}

A most harmful aspect of slavery's legacies is racism, which involves both conscious and unconscious racism within overt and covert racialized systems in contemporary western societies. The harm manifests as internalized racism or self-violence, interpersonal racism or antagonistic intercommunal relations, and structural racism and institutionalized discrimination. ${ }^{68}$ Typically, these different forms of racism are treated separately, and few attempts are made to explore their interconnections. Therefore, a closer examination of these mutually constituted dimensions of racism is necessary to discern the relevant contemporary harms.

Internalized racism refers to the application of racist attitudes, beliefs, or ideologies within an actor's worldview, often manifested in two forms-internalized dominance and internalized oppression. Internalized dominance describes and explains experiences, attitudes, and privileges of people belonging to powerful identity groups. It is a socially superior status accepted, experienced, and profited from, consciously and unconsciously, by dominant groups, which in the case of contemporary western societies, white people in Europe, and peoples of European descent in the Americas, as normalized and deserved. By contrast, internalized oppression describes and explains "the experience of those who are members of subordinated, marginalized, or minority groups; those who are powerless and often victimized, both intentionally and unintentionally, by members of dominant groups;" 69 and those who have adopted the dominant groups' beliefs, attitudes and ideology and have thereby accepted their subordinate status as deserved, normal, and inevitable. ${ }^{70}$

The experiences of internalized oppression and their long-term negative physical and psychological consequences for black people have been well-documented, and amongst the harms are the shame associated with "African-ness, as a result of slavery and racism, and the shame of being shamed,"71 alienation, both self-alienation and alienation from one's own group/community, 72 as well as powerlessness and marginalization. ${ }^{73}$ Indeed, Afro-descendants worldwide who experience higher levels of racial discrimination tend to have greater internalized racism. ${ }^{74}$ As such, they must battle against two forces simultaneously: the

67 Derek Hook, "Fanon and the Psychoanalysis of Racism," LSE Research Online (London: LSE Research Online, 2007), accessed April 20, 2021, http://eprints.lse.ac.uk/2567.

68 Michael Omi and Howard Winant, Racial Formation in the United State (New York: Routledge, 2015); Yin C. Paradies, "Defining, Conceptualizing and Characterizing Racism in Health Research," Critical Public Health 16, no. 2 (2006).

${ }^{69}$ Mark B. Tappan, “Reframing Internalized Oppression and Internalized Domination: From the Psychological to the Sociocultural," Teachers College Record 108, no. 10 (2006), 2116.

${ }^{70}$ Ibid.

${ }^{71}$ David Watts-Jones, "Healing Internalized Racism: The Role of a Within-Group Sanctuary Among People of African Descent," Family Process 41, no. 4 (2002).

72 Paulo Freire, Pedagogy of the Oppressed (New York: Continuum, 1970); Laura M. Padilla, “'But You're Not a Dirty Mexican:' Internalized Oppression, Latinos \& Law," Texas Hispanic Journal of Law \& Policy 7, no. 1 (Fall 2001).

73 Suzette L. Speight, “Internalized Racism: One More Piece of the Puzzle," The Counseling Psychologist 35, no. 1 (January 2007), accessed April 21, 2021, http:/ / doi.org/10.1177/0011000006295119.

74 E. J. R. David et al., "Internalized Racism: A Systematic Review of the Psychological Literature on Racism's Most Insidious Consequence," Journal of Social Issues 75 (September 2019), 1057-1086, accessed April 21, 2021, https:// doi.org/10.1111/josi.12350. 
oppressive force within, the oppressive structure in the society. In the case of oppressive force within, internalized racism can be expressed as a desire for more European features (e.g., body size, hair texture) and a denigration of African features (physical and character traits). ${ }^{75}$ Internalized racism is not limited to African diaspora, and can be experienced by peoples living in Africa, such as the phenomenon of African women's skin bleaching. Internalized oppression can be experienced as self-hatred, feelings of inferiority, resignation, isolation, alienation, and powerlessness. It can inadvertently sustain a cultural normalcy intending to oppress. For example, within a racist system, people of African descent can readily accept and participate in the hierarchical social structure, ${ }^{76}$ and even actively reproduce subordination and perpetuate domination from the white people. ${ }^{77}$ This is because it is within structural violence and institutional discrimination that racialized subjects experience their lived realities..$^{78}$

Whenever the internally oppressed are treated as "victims" of their own psychological state, and their experience diagnosed as a psychological issue, internalized racism is reduced to a personal attitudinal problem. Hence personal bias, self-prejudice, or pure ignorance, as the result of internalized racism, is treated with therapy, encounter, and education. ${ }^{79}$ Such reduction is pernicious in a contemporary racist society because it willfully ignores the systemic nature of racism, and lays the blame to the very people who are oppressed. Indeed, a person's desires and self-concept (e.g., a black person desiring to be white) cannot be separated from the relevant socioeconomic, political, and historical forces that converge and shape them. ${ }^{80}$ Instead, they reflect the workings of power, which are necessarily structural..$^{81}$

Like internalized racism, interpersonal racism can have agonizing impacts on intercommunal, intergroup, international, and even global relationships. ${ }^{82}$ Interpersonal racism equally has structural roots. That is to say that transatlantic slave trade, colonial expansion, post-colonial domination, and globalization have all been built upon unequal power relations structurally shaped and imposed predominantly by Western and neoliberal views of the world. ${ }^{83}$ This worldview gives rise to our contemporary global economic system that legitimizes Western/white dominance over the different Others, especially peoples of African and indigenous descent. Thus, within an economic system that institutionalizes discrimination, "we have all been programmed to respond to the human difference between us with fear and loathing and to handle that difference in one of three ways: ignore it, and if that is not possible, copy it if we think it is dominant, or destroy it if we think it is subordinate. ${ }^{84}$ There have been few patterns of relating that enable people to experience each other as equals across differences.

The prevalent racist patterns of relating are characterized by inhumanity, discrimination, and domination, reflecting the white-black duality of self- and other-

75 Danice L. Brown and Daniel Segrist, "African American Career Aspirations," Journal of Career Development 43, no. 2 (May 2016), accessed April 20, 2020, https://doi.org/10.1177/0894845315586256; Fanon, Black Skin, 197.

76 Tanya Golash-Boza, "A Critical and Comprehensive Sociological Theory of Race and Racism," Sociology of Race and Ethnicity 2, no. 2 (February 2016), accessed April 20, 2021, https:/ / doi.org/10.1177\%2F2332649216632242.

77 Miri Song, "Challenging a Culture of Racial Equivalence," The British Journal of Sociology 65, no. 1 (March 2014); Iris Marion Young, Justice and the Politics of Difference (Princeton: Princeton University Press, 1990); Mark B. Tappan, "Domination, Subordination, and the Dialogical Self: Identity Development and the Politics Of 'Ideological Becoming,'” Culture and Psychology 11, no. 1 (2005).

78 José Itzigsohn and Karida Brown, "Sociology and the Theory of Double Consciousness: W. E. B. Du Bois's Phenomenology of Racialized Subjectivity," Du Bois Review: Social Science Research on Race 12, no. 2 (Fall 2015), accessed April 20, 2021, https:// doi.org/10.1017/S1742058X15000107.

79 Tappan, Reframing.

${ }^{80}$ Fanon, Black Skin.

${ }^{81}$ Hook, Fanon.

82 UNESCO Slave Route Project and GHFP, Healing the Wounds of Slave Trade and Slavery. Approaches and Practices: A Desk Review (Brighton: GHFP Research Institute, 2020).

83 Thiaw and Mack, Atlantic Slavery.

${ }^{84}$ Audre Lorde, "Age, Race, Class, and Sex: Women Redefining Difference," in Sister Outsider: Essays and Speeches (Berkley: Crossing Press, 1984), 115. 
recognition. 85 This is the result of pernicious ignorance of ourselves as spiritual and ethical beings. ${ }^{86}$ It is pernicious because the ignorance can cause harm, not only to other people but also to oneself. Socially constructed self-identification is built upon a mutual dependency of different identity groups in recognizing each other's positionality in the societal "game," 87 which effectively determines how people in each identity group are perceived, valued, received, and engaged with relationally. 88 Racialization has damaging effects on intergroup and intercommunal relationships. When people adopt an inhumane attitude about others, and worse, when they internalize the inhuman attitude about themselves, they tend to take an indifferent, distancing, and objectifying orientation towards each other. ${ }^{89}$

Interpersonal and intergroup relationships thus shaped by racist structural and institutional conditions can have traumatic effects on people physically, psychologically, socialrelationally, and spiritually. Such harms are perpetuated through "normal" processes of daily lives of people, ${ }^{90}$ including self-identification, the experiences of living in one's own skin, the encounters with racialized attitudes, and, above all, the relationships within which people are born, grow and become themselves.

Therefore, race-based self-identification and its harmful effects on intergroup and intercommunal relationships must be equally understood as historically, socio-economically, and politically defined processes. ${ }^{91}$ That is to say that race is not only defined in relational terms within socio-economic and political spaces, it also reflects systemic, cultural, and symbolic negotiations of power. ${ }^{92}$ As systemic racism configures the workings and mechanisms of institutions, at a micro-sociological level, racialized harms are built into people's lived realities through everyday routines and practices. ${ }^{93}$ For example, an obvious reason underlying the endemic of poverty in black communities in contemporary western societies is owing to, amongst other factors, an unjust educational system.94 This includes uneven educational finance, the lack of sensitivity to racial prejudices and color blindness amongst teachers, and the systematic exclusion of black and indigenous children and young people from quality public education. 95

Therefore, harms of racism cannot be understood outside the racist socio-economic and political structure and institutions, and the problem of the 21st century will continue to be the problem of the color line as a major legacy inherited from previous centuries. ${ }^{96}$ In other words, although racism exists and operates at these three levels, e.g., internalized, interpersonal, and institutional, it can be felt as if it is constituted in and integral to one's lived reality, and as such,

85 Cheryl I. Harris, “Whiteness as Property,” Harvard Law Review 106, no. 8 (June 1993).

86 Scherto Gill and Garrett Thomson, Understanding Peace Holistically From the Spiritual to the Political (New York: Peter Lang, 2018).

87 George Herbert Mead, George Herbert Mead on Social Psychology, ed. Anselm Strauss (Chicago: University of Chicago Press, 1964).

88 Nathan Nunn and Leonard Wantchekon, "The Slave Trade and the Origins of Mistrust in Africa," American Economic Review 101, no. 7 (December 2011).

89 Haslam, Dehumanization.

90 Young, Justice, 14.

91 Matthew W. Hughey and Carol Ann Jackson, "The Dimensions of Racialization and the Inner-City School," The ANNALS of the American Academy of Political and Social Science 673, no. 1 (September 2017).

92 James Y. Nazroo et al., "Where Next for Understanding Race/Ethnic Inequalities in Severe Mental Illness? Structural, Interpersonal and Institutional Racism," Sociology of Health E Illness 42, no. 2 (April 2020), accessed April 21, 2021, https:// doi.org/10.1111/1467-9566.13001.

93 Ibid.

94 Julio Cammarota, "The Gendered and Racialized Pathways of Latina and Latino Youth: Different Struggles, Different Resistances in the Urban Context," Anthropology E Education Quarterly 35, no. 1 (January 2008), accessed April 21, 2021, https: / / doi.org/10.1525/aeq.2004.35.1.53.

95 David Gillborn, Racism and Education: Coincidence or Conspiracy? (London: Routledge, 2008).

96 John Hope Franklin, The Color Line: Legacy for the Twenty-First Century (Columbia: University of Missouri Press, 1993). 
"it can be difficult to discern, like the water we swim in or the air we breathe." 97 Both internalized dominance and internalized oppression prevent the possibility of congenial relationships amongst peoples and groups seemingly separated by the colors of their skin. Similarly, relational processes, social interactions, and collective emotional state are always already framed and actualized through the systemic, such as economic systems, social policies, laws, tax regime, etc. They are then enabled by and enacted through the institutional, such as cultures and practices within families, neighborhoods, schools, shops, hospitals, workplaces, police force, prisons, and so forth. Whilst the systemic creates the macro environment and conditions, it is through the micro processes and mechanisms that the structural characteristics are realized, and the enduring harms of the transatlantic slave trade are felt most keenly.

Above all, it is the moral and spiritual harms that are most damaging, including the discriminative conceptions of whiteness as "good" and "superior," and blackness as "evil" and "inferior," the active othering of non-Europeans, and the resulting negative and antagonistic self- and other-identification, failing to recognize our own and each other's inherent dignity. ${ }^{98}$ There is also a growing ethical blindness in the face of self-alienation, both of which are keeping humanity hostage. In this sense, slavery's legacy "is more cruel than the shackles on the wrists and ankles." 99 Trauma and racism rooted in the power structure in contemporary western societies continue to determine social domination of an "inferior race" by a "superior race," extending systemic oppression to the Caribbean, Latin America, Africa and beyond. 100

\section{Conclusion}

This article explores the historical impacts of the transatlantic trade of enslaved Africans and slavery, and examines the continuing harmful effects on peoples, groups, and communities in relevant contemporary societies. Through interdisciplinary analysis of these legacies, and by making a distinction between slavery's legacies and their multi-faceted harms, it has developed an understanding that slavery's legacy is a living legacy, and that its damages are not merely historical, they are simultaneously personal, relational, socio-cultural, structural, and institutional. By highlighting the interconnection of the legacy, the traumas, the resultant harms, and the systemic root of dehumanization, this article invites constructive reflections on how global societies and communities must act now to address this legacy and heal its embittering wounds.

To begin, we consider the moral lessons this article's investigation is offering. The first is at the level of self- and other-identification. It is indeed our lack of mutual human recognition which lies at the foundation of our collective tragedy. This is a tragedy because when humans fail to identify other persons as equally human, we also disregard our own human dignity. The second lesson is that contemporary experiences of economic oppression, political exclusion, social discrimination, and self-alienation have roots in historical racialization, commodification and instrumentalization of people of African, indigenous and other non-European descents. The third is that our global economic processes, national political systems, and institutional cultures and practices have served to extend the atrocity of slavery and the persistent damage of its legacy. ${ }^{101}$ These lessons give rise to key ethical questions in our imagination of ways to liberate global community from inhumanity and antagonism. For instance, in all these considerations, what might be the fundamental ethical principle(s) upon which to situate racial equity and

\footnotetext{
${ }^{97}$ Speight, Internalized Racism, 127.

98 Frances Kendall, Understanding White Privilege: Creating Pathways to Authentic Relationships Across Race, 2nd ed. (London: Routledge, 2013).

99 Na'im Akbar, Chains and Images of Psychological Slavery (Jersey City: New Mind Productions, 1984), 132; Speight, Internalized Racism.

100 Jemima Pierre, "Slavery, Anthropological Knowledge, and the Racialization of Africans," Current Anthropology 61, no. S22 (October 2020).

101 Pascale De Souza and H. Adlai Murdoch, "Editorial Introduction" to "Oceanic Dialogues: from the Black Atlantic to the Indo-Pacific," International Journal of Francophone Studies 8, no 2 (December 2005).
} 
human solidarity? Du Bois writes: "The slave went free; stood for a brief moment in the sun; then moved back again toward slavery." 102 What might constitute "the sun?" How might we liberate humanity from the prolonged darkness of psychological slavery?

To consider such questions, it might require imagining a number of processes at the same time: one is a collective reckoning with our shared dehumanizing history, acknowledging the mass atrocity and large scale "psychosis."103 This will necessarily involve emotional, cognitive, and ethical approaches, such as listening empathetically to the truths of people's lived experiences, whilst examining systemic violence and institutional processes, and established cultural norms that define different groups' lived realities. It also demands us to transcend ignorance, overcome indifference, and become proactive in our taking responsibility. This caring matters because only with such an ethical commitment can we move from witnessing, to understanding, to developing shared pathways towards addressing the root causes of human suffering. ${ }^{104}$

Given the article's highlighting the complex processes involved in people's experiences of self- and other- alienation, it suggests that inhuman relationships cannot simply be removed by encouraging people to adopt mutual human-recognition because this recognition on its own would not legitimize mutual belonging. Structural racism, cultural disenfranchisement, and dehumanizing institutional practices will continue to demarcate the struggle of people of African and indigenous descents for emancipative self-identification. Thus, Du Bois proposes a way forward by transcending this dialectic and "affirming it in a permanent tension. Henceforth, the destiny of the race could be conceived as leading neither to assimilation nor separatism but to proud, enduring hyphenation." 105

As our shared ethical life is rooted in communities defined by common freedom, rather than the freedom of specific groups, to develop hyphenated self-identification might require community-rooted deep sharing, collective healing and collaborative action that help enrich solidarity amongst all people. 106 Interpersonal encounter, human affinity, and mutual affective experience can give rise to ethical responsibility for each other's well-being, and human becoming. ${ }^{107}$ Similarly, to step outside the black/white binary view of humanity is to give way to subjectivity conceived as intersubjectivity. 108 This conceptual position can help societies move beyond race, and beyond any form of essentialization in defining groups and communities based on skin colors, physical features, or even cultural rituals. 109

A significant approach to addressing the personal, relational, structural, and institutional harms is through the pathway of education. By education, we do not mean the kind that will reproduce the stifling and inhumane relationships between people, and communities, nor the kind that will sustain the existing status quote. Instead, by education, we are seeking the kind of teaching and learning that is not only constituted in an "overt resistance to racist practices," 110 but is ultimately about providing spaces and processes that can enable children and young people to learn to become more fully human together, and to act out our mutual belongingness and caring. To truly allow humanity to flourish and to stand in the sun, to use Du Bois" metaphor, is to instill humanizing values, and to educate a person "to be

\footnotetext{
102 W. E. B. Du Bois, Black Reconstruction in America (New York: The Free Press, 1935), 30.

103 Kehinde Andrews, “The Psychosis of Whiteness: The Celluloid Hallucinations of 'Amazing Grace' and 'Belle,'” Journal of Black Studies 47, no. 5 (March 2016).

${ }^{104}$ Kwame Anthony Appiah, Cosmopolitanism: Ethics in a World of Strangers (London: Penguin Books, 2006).

105 David Levering Lewis, W. E. B. Du Bois Biography of Race, 1868-1919 (New York: Henry Holt \& Co., 1993), 281.

106 Charles Taylor, Sources of the Self: The Making of the Modern Identity (Cambridge: Harvard University Press, 1989).

107 Freire, Pedagogy.

108 Paul Gilroy, Against Race: Imagining Political Culture Beyond the Color Line (Cambridge: Harvard University Press, 2002).

109 Gilroy, The Black Atlantic.

110 Shirley J. Yee, Black Women Abolitionists: A Study in Activism, 1828-1860 (Knoxville: University of Tennessee Press, 1993), 49.
} 
actional, preserving in all his relations respect for the basic values that constitute a human world." 111

\section{Bibliography}

Acemoglu, Daron, Simon Johnson, and James A. Robinson. "Institutions as a Fundamental Cause of Long-Run Growth.' In Handbook of Economic Growth Vol 1A. Edited by Philippe Aghion and Steven N. Durlauf. 385-472. Amsterdam: Elsevier: 2005.

Akbar, Na'im. Chains and Images of Psychological Slavery. Jersey City: New Mind Productions, 1984.

Alexander, Jeffery C., Ron Eyerman, Bernhard Giesen, Neil J. Smelser, and Piotr Sztompka. Cultural Trauma and Collective Identity. Berkeley: University of California Press, 2004.

Andrews, Kehinde. "The Psychosis of Whiteness: The Celluloid Hallucinations of 'Amazing Grace' and 'Belle.'” Journal of Black Studies 47, no. 5 (March 2016), 435-453.

Appiah, Kwame Anthony. Cosmopolitanism: Ethics in a World of Strangers. London: Penguin Books, 2006.

Banton, Michael. "Race as a Social Category." Race 8, no. 1 (July 1966), 1-16.

Baptist, Edward. The Half Has Never Been Told: Slavery and the Making of American Capitalism. New York: Basic Books, 2016.

Bar-On, Dan. The Indescribable and the Undiscussable: Reconstructing Human Discourse After Trauma. Budapest: Central European University Press, 1999.

Beckert, Sven. Empire of Cotton: A Global History. London: Vintage, 2015.

Beckert, Sven and Seth Rockman, eds. Slavery's Capitalism: A New History of American Economic Development. Philadelphia: University of Pennsylvania Press, 2016.

Berlin, Ira. Generations of Captivity: A History of African-American Slaves. Cambridge: Harvard University Press, 2003.

Bertocchi, Graziella. "The Legacies of Slavery In and Out of Africa." IZA Journal of Migration 5 (August 2016). Accessed April 21, 2021. https://izajodm.springeropen.com/articles/ 10.1186/s40176-016-0072-0.

Brown, Danice L. and Daniel Segrist. "African American Career Aspirations." Journal of Career Development 43, no. 2 (May 2016), 177-189. Accessed April 20, 2020. https://doi.org/ $10.1177 / 0894845315586256$.

Cammarota, Julio. "The Gendered and Racialized Pathways of Latina and Latino Youth: Different Struggles, Different Resistances in the Urban Context." Anthropology $\mathcal{E}$ Education Quarterly 35, no. 1 (January 2008), 53-74. Accessed April 21, 2021. https:// doi.org/10.1525/aeq.2004.35.1.53.

Champagne, Frances A. "Epigenetic Legacy of Parental Experiences: Dynamic and Interactive Pathways to Inheritance." Development and Psychopathology 28, no. 4.2 (Sept 2016), 12191228. Accessed November 7, 2021. https:// doi.org/10.1017/S0954579416000808.

Curran, Andrew S. The Anatomy of Blackness: Science and Slavery in an Age of Enlightenment. Baltimore: Johns Hopkins University Press, 2011.

David, E. J. R., Tiera M. Schroeder, and Jessicaanne Fernandez. "Internalized Racism: A Systematic Review of the Psychological Literature on Racism's Most Insidious Consequence." Journal of Social Issues 75 (September 2019), 1057-1086. Accessed April 21, 2021. https:// doi.org/10.1111/josi.12350.

DeGruy Leary, Joy. Post Traumatic Slave Syndrome: America's Legacy of Enduring Injury and Healing. Milwaukie: Uptone Press, 2005.

De Souza, Pascale and H. Adlai Murdoch. "Editorial Introduction" to "Oceanic Dialogues: from the Black Atlantic to the Indo-Pacific." International Journal of Francophone Studies 8, no 2 (December 2005), 133-146.

\footnotetext{
111 Fanon, Black Skin, 173.
} 
dos Santos Reis, Diego. "Crossroads Knowledge: (De)Coloniality, Epistemic Racism and Philosophy eaching," Education, Democracy and Difference 36, no. e75102 (2020).

Douglas, Andrew J. “W. E. B. Du Bois and the Critique of the Competitive Society." Du Bois Review: Social Science Research on Race 12, no. 1 (January 2015), 25-40. Accessed April 21, 2021. https:// doi.org/10.1017/S1742058X14000344.

Du Bois, William E. B. Black Reconstruction in America. New York: The Free Press, 1935.

------. The Souls of Black Folk. Boston: Bedford Books, 1903. The W.E.B. Du Bois Collection. New York: Blackmore Dennett, 1999.

Eyerman, Ron. Cultural Trauma: Slavery and the Formation of African American Identity. Cambridge: Cambridge University Press, 2001.

Fanon, Franz. Black Skin, White Masks. Translated by Charles Lam Markmann. London: Pluto Press, 1986.

Faustino, Deivison M. "The Wretched of COVID-19 in Brazil: Colonial Spectres of an Announced Crisis." Agrarian South: Journal of Political Economy 10, no. 1 (April 2021), 173-183.

Fishman, Laura T. "The Black Bogeyman and White Self-Righteousness." In Images of Color, Images of Crime, edited by Coramae Richey Mann, Marjorie S. Zatz, and Nancy Rodriguez, 197-211. New York: Oxford University Press, 2006.

Fletchman Smith, Barbara. Mental Slavery: Psychoanalytic Studies of Caribbean People. London: Karnac Books, 2000.

Franklin, John Hope. The Color Line: Legacy for the Twenty-First Century. Columbia: University of Missouri Press, 1993.

Freire, Paulo. Pedagogy of the Oppressed. New York: Continuum, 1970.

Gill, Scherto and Garrett Thomson. Understanding Peace Holistically: From the Spiritual to the Political. New York: Peter Lang, 2018.

Gillborn, David. Racism and Education: Coincidence or Conspiracy?. London: Routledge, 2008.

Gilroy, Paul. Against Race: Imagining Political Culture Beyond the Color Line. Cambridge: Harvard University Press, 2002.

The Black Atlantic: Modernity and Double Consciousness. London: Verso, 1993.

Goff, Philip Atiba, Jennifer L. Eberhardt, Melissa J. Williams, and Matthew Christian Jackson. "Not Yet Human: Implicit Knowledge, Historical Dehumanization, and Contemporary Consequences." Journal of Personality and Social Psychology 94, no. 2 (March 2008), 292306.

Golash-Boza, Tanya. "A Critical and Comprehensive Sociological Theory of Race and Racism." Sociology of Race and Ethnicity 2, no. 2 (February 2016), 129-141. Accessed April 20, 2021. https:// doi.org/10.1177\%2F2332649216632242.

Gordon-Reed, Annette. "America's Original Sin: Slavery and the Legacy of White Supremacy." Foreign Affairs 97, no. 1 (January/February 2018), 2-7.

Harris, Cheryl I. "Whiteness as Property." Harvard Law Review 106, no. 8 (June 1993), 1707-1791.

Haslam, Nick. "Dehumanization: An Integrative Review." Personality and Social Psychology Review 10, no. 3 (August 2006), 252-264.

Hughey, Matthew W. and Carol Ann Jackson. "The Dimensions of Racialization and the InnerCity School." The ANNALS of the American Academy of Political and Social Science 673, no. 1 (September 2017), 312-329.

Hook, Derek. "Fanon and the Psychoanalysis of Racism." LSE Research Online. London: LSE Research Online, 2007. Accessed April 20, 2021. http://eprints.lse.ac.uk/2567.

Hübl, Thomas and Julie Jordan Avritt. Healing Collective Trauma: A Process for Integrating Our Intergenerational and Cultural Wounds. Louisville: Sounds True, 2020.

Itzigsohn, José and Karida Brown. "Sociology and the Theory of Double Consciousness: W. E. B. Du Bois's Phenomenology of Racialized Subjectivity." Du Bois Review: Social Science Research on Race 12, no. 2 (Fall 2015), 231-248. Accessed April 20, 2021. https:/ / doi.org/ $10.1017 / \mathrm{S} 1742058 \times 15000107$. 
Johnson, Walter. "To Remake the World: Slavery, Racial Capitalism, and Justice." Boston Review, February 20, 2018. Accessed April 20, 2021. http://bostonreview.net/forum/walterjohnson-to-remake-the-world.

Kelley, Robin D. G. “What did Cedric Robinson Mean by Racial Capitalism?.” Boston Review. January 12, 2017. Accessed April 20, 2021. http://bostonreview.net/race/robin-d-gkelley-what-did-cedric-robinson-mean-racial-capitalism.

Kendall, Frances. Understanding White Privilege: Creating Pathways to Authentic Relationships Across Race, 2nd ed. New York: Routledge, 2013.

Lewis, David Levering. W. E. B. Du Bois Biography of Race, 1868-1919. New York: Henry Holt \& Co., 1993.

Lorde, Audre. "Age, Race, Class, and Sex: Women Redefining Difference." In Sister Outsider: Essays and Speeches. Berkley: Crossing Press, 1984.

Lovejoy, Paul E. Transformations in Slavery: A History of Slavery in Africa. Cambridge: Cambridge University Press, 2012.

Martin, Michael T. and Marilyn Yaquinto. “Reparations for 'America's Holocaust:' Activism and Global Justice." Race and Class 45, no. 4 (April 2004), 1-25.

Marx, Karl. "Economic and Philosophical Manuscripts of 1844." In Early Writings. Translated by Rodney Livingstone and Gregor Benton. London: Penguin, 1992.

McKee, James B. "Race: Changing Context, Changing Perspective." Michigan Sociological Review 11 (Fall 1997), 1-17.

Mead, George Herbert. George Herbert Mead on Social Psychology. Edited by Anselm Strauss. Chicago: University of Chicago Press, 1964.

Mills, Charles W. The Racial Contract. Ithaca: Cornell University Press, 1997.

Nazroo, James Y., Kamaldeep S. Bhui, and James Rhodes. "Where Next for Understanding Race/Ethnic Inequalities in Severe Mental Illness? Structural, Interpersonal and Institutional Racism." Sociology of Health E Illness 42, no. 2 (April 2020), 262-276. Accessed April 21, 2021. https:// doi.org/10.1111/1467-9566.13001.

Nunn, Nathan and Leonard Wantchekon. "The Slave Trade and the Origins of Mistrust in Africa." American Economic Review 101, no. 7 (December 2011), 3221-3252.

Omi, Michael, and Howard Winant. Racial Formation in the United States. New York: Routledge, 2015.

Owusu-Bempah, Akwasi. "Race and Policing in Historical Context: Dehumanization and the Policing of Black People in the 21st Century." Theoretical Criminology 21, no. 1 (February 2017), 23-34.

Padilla, Laura M. “'But You're Not a Dirty Mexican:' Internalized Oppression, Latinos \& Law.” Texas Hispanic Journal of Law E Policy 7, no. 1 (Fall 2001), 59-113.

Paradies, Yin C. "Defining, Conceptualizing and Characterizing Racism in Health Research." Critical Public Health 16, no. 2 (2006), 143-157.

Phillips, Coretta and Benjamin Bowling, "Racism, Ethnicity and criminology: Developing Minority Perspectives." British Journal of Criminology 43, no. 2 (March 2003), 269-290.

Pierre, Jemima. "Slavery, Anthropological Knowledge, and the Racialization of Africans." Current Anthropology 61, no. S22 (October 2020), S220-S231.

Rahier, Jean Muteba. "Evaluating the Usefulness of Contemporary Ethnoracial Law for Afrodescendants in Latin America through the Examination of Court Cases and the Appreciation of the State's Processual Nature," Latin American and Caribbean Ethnic Studies 14, no. 3 (2019), 215-233.

Ralph, Michael and Maya Singhal. "Racial Capitalism." Theory and Society 48, (Dec 2019), 851881. Accessed April 21, 2021. https:/ / doi.org/10.1007/s11186-019-09367-z.

Ramose, Mogobe B. African Philosophy Through Ubuntu. Harare: Mond Books, 1999.

Robinson, Cedric J. Black Marxism: The Making of the Black Radical Tradition. Chapel Hill: University of North Carolina Press, 1983.

Said, Edward W. Orientalism. New York: Vintage, 1979. 
Salenius, Sirpa. "Troubling the White Supremacy-Black Inferiority Paradigm: Frederick Douglass and William Wells Brown in Europe." Journal of Transatlantic Studies 14, no. 2 (2016), 152-163.

Song, Miri. "Challenging a Culture of Racial Equivalence." The British Journal of Sociology 65, no. 1 (March 2014), 107-129.

Speight, Suzette L. "Internalized Racism: One More Piece of the Puzzle." The Counseling Psychologist 35, no. 1 (January 2007), 126-134. Accessed April 21, 2021. http://doi.org/ $10.1177 / 0011000006295119$.

Spivak, Gayatri. "Can the Subaltern Speak?." In Marxism and the Interpretation of Culture, edited by Cary Nelson and Lawrence Grossberg, 271-313. London: Macmillan, 1988.

Stelzner, Mark. "Slavery and Capitalism." Labor History 61, no. 3-4 (April 2020), 335-347.

Stiglitz, Joseph E. The Price of Inequality: How Today's Divided Society Endangers Our Future. New York: W. W. Norton \& Company, 2012.

Tappan, Mark B. "Domination, Subordination, and the Dialogical Self: Identity Development and the Politics Of 'Ideological Becoming.'" Culture and Psychology 11 (2005), 47-75.

. "Reframing Internalized Oppression and Internalized Domination: From the Psychological to the Sociocultural." Teachers College Record 108, no. 10 (2006), 2115-2144.

Taylor, Charles. Sources of the Self: The Making of the Modern Identity. Cambridge: Harvard University Press, 1989.

Thiaw, Ibrahima and Deborah L. Mack. "Atlantic Slavery and the Making of the Modern World: Experiences, Representations, and Legacies." Current Anthropology 61, no. S22 (October 2020) S145-S158.

UNESCO Slave Route Project. Healing the Wounds of Slave Trade and Slavery. Approaches and Practices: A Desk Review. Brighton: GHFP Research Institute, 2020.

Van Cleve, Nicole Gonzalez, and Lauren Mayes. "Criminal Justice Through 'Colorblind' Lenses: A Call to Examine the Mutual Constitution of Race and Criminal Justice." Law \& Social Inquiry 40, no. 2 (February 2015), 406-432. Accessed April 21, 2021. https://doi.org/ 10.1111/lsi.12113.

Volkan, Vamik D. Large-Group Psychology: Racism, Societal Divisions, Narcissistic Leaders and Who We Are Now. London: Phoenix, 2020.

Watts-Jones, David. "Healing Internalized Racism: The Role of a Within-Group Sanctuary Among People of African Descent." Family Process 41, no. 4 (2002), 591-601.

West, Cornel. Race Matters. Boston: Beacon Press, 1993.

Wiesel, Elie. Night. New York: Bantam Books, 1960.

Williams, Eric. Capitalism and Slavery. London: University of North Carolina Press, 1994.

Woodson, Carter G. The Mis-Education of the Negro. San Diego: Book Tree, 1933.

Yee, Shirley J. Black Women Abolitionists: A Study in Activism, 1828-1860. Knoxville: University of Tennessee Press, 1993.

Yehuda, Rachel, and Linda M. Bierer. "The Relevance of Epigenetics to PTSD: Implications for the DSM-V." Journal of Traumatic Stress 22, no. 5 (October 2009), 427-434. Accessed April 21, 2021. https:// doi.org/10.1002/jts.20448.

Young, Iris Marion. Justice and the Politics of Difference. Princeton: Princeton University Press, 1990. 